\title{
Space Matters? Exploring Gender Differentials in the Age at Marriage, Greece (1980-2017)
}

\author{
Kostas Rontos ${ }^{1}$ and Luca Salvati ${ }^{2,3, *}$ \\ 1 Department of Sociology, University of the Aegean, EL-81100 Mytilene, Greece; k.rontos@soc.aegean.gr \\ 2 Department of Economics and Law, University of Macerata, Via Armaroli 43, I-62100 Macerata, Italy \\ 3 Global Change Research Institute of the Czech Academy of Sciences, Lipová 9, \\ CZ-37005 České Budějovice, Czech Republic \\ * Correspondence: luca.salvati@unimc.it
}

Received: 24 March 2020; Accepted: 17 April 2020; Published: 23 April 2020

check for updates

\begin{abstract}
Although local context is considered a key factor shaping differences in the age at marriage between spouses, spatially explicit investigations of the gender gap in marriage timing were scarce in Europe, especially in more traditional societies. The present study analyses the spatial distribution of the gender age gap at marriage in Greece, a country experiencing a late demographic transition compared with other European societies. Analysis of prefecture-level data between 1980 and 2017 indicates a continuous increase in the age at marriage, with a moderate reduction in the gender age gap (5 and 3 years respectively in 1980 and 2017). While in the early 1980s age differentials at marriage between men and women diverged in rural and urban areas, a reduced gender gap and greater spatial heterogeneity were observed in 2017, indicating social modernization in most rural communities. These findings highlight the role of local contexts in shaping attitudes toward marriage postponement in Greece, suggesting that the spatial diffusion of marriage homogamy-as an indicator of social change-is influenced by the emergence of 'permeable' and 'resistant' communities with characteristic socioeconomic profiles. Going beyond the traditional urban-rural divide, space has become an important mediator of gender power dynamics, evidencing the progressive fragmentation of social processes and the increasing heterogeneity of the related demographic patterns at the local community scale. Spatial analysis contributes to delineate such complex processes, integrating results from approaches that assess individual behaviors with a refined investigation of macro-scale patterns of change.
\end{abstract}

Keywords: local context; traditional societies; attitudes toward marriage; indicators; spatial analysis; Mediterranean region

\section{Introduction}

With modernization and globalization, heterogeneous population dynamics over time and space have characterized contemporary societies, resulting in new types of households and lifestyles (Martin 1992; Lee and Reher 2001; Lee 2003; Blue and Espenshade 2011). Beyond decreasing fertility and aging, demographic transitions were considered "a pathway to change" leading to a delay in marriage (Billari and Kohler 2004; Rindfuss et al. 2004; Morgan and Taylor 2006; Kreyenfeld et al. 2012; Balbo et al. 2013; Sobotka et al. 2017). More specifically, the role of 'marriage' has transformed around the world (Bongaarts 2003; Pinnelli and Cesare 2005; Seltzer et al. 2005; Ortega 2014; Yoo 2016; Rontos et al. 2017). Social homogamy (i.e., marriage between individuals with comparable socio-demographic features: Burgess and Wallin 1943), is a relatively common pattern in many countries, and is sometimes reflective of declining social openness. Age homogamy (i.e., marriage between individuals of similar ages) is considered one of the most diffused forms of homogamy (Van Poppel et al. 2001; Blossfeld 2009; 
Van de Putte et al. 2009). In this regard, "the level of age homogamy is also an important indicator of social closure and gender inequality, as large age differences between spouses have been associated with more patriarchal family systems and less spousal intimacy" (Mu and Xie 2014, p. 141).

Earlier studies have been developed with the aim at investigating the age at marriage, its determinants and impact on family formation, e.g., in Europe (Kiernan 1988; Morsa 1985; Voland and Dunbar 1997), in the USA (Perreira 1991, UNECE 2003), and in Asian countries (Johansson et al. 1996; Nguyen 1997; Lofstedt et al. 2005; Hong 2006; Islam and Ahmed 1998; Palmore and Singarimbun 1992). Although the normative timetable for the age at marriage varies with gender, socioeconomic status and region (Van Poppel and Nelissen 1999), relevant patterns in most places were changing towards a significant increase in the age at marriage. In these regards, age at marriage is a variable studied extensively with the aim to define changes in demographic patterns and socioeconomic transitions according to different background conditions and local contexts (Bumpass 1969; Bytheway 1981; Lesthaeghe 1983; Bozon 1991; Malhotra 1997; Billari et al. 2007). In these regards, the statistical distribution of marriages by age was investigated using macro-scale approaches or micro-scale models (e.g., Coale and McNeil 1972; Coale and Trussell 1996; Billari 2015). Considering individual heterogeneity as a crucial element for analysis of age patterns (Bijak et al. 2013), agent-based models of marriage were also developed adopting age-specific marriage rates as a target (Billari 2000).

Less attention has been given to study long-term trends in the gender age gap at marriage especially in traditional, and rapidly changing, societies. Empirical approaches based on a spatially explicit analysis of gender differentials in the age at marriage may better clarify the role of regional contexts (Kulu 2011) and place-specific socioeconomic forces (England and McClintock 2009) in selected aspects of demographic transition in advanced economies (Haandrikman et al. 2008). Differential changes over time in the age at marriage of males and females were supposed to reflect regional and local socioeconomic transformations (e.g., Neels and De Wachter 2010), weakening the traditional divide in urban and rural contexts (Malhotra 1997). However, although contextual factors are demonstrated to impact significantly age at marriage for both males and females, spatially explicit investigations of marriage timing and the associated gender gap are relatively scarce in the European context (Haandrikman 2014).

Thanks to multiple social forces interacting at micro- and macro-scales, age at marriage in Europe was systematically higher than elsewhere in the world, with a relatively low gender age gap indicating moderate (and likely decreasing) social inequalities (Atkinson and Glass 1985; Kalmijn 2007; Dennison and Ogilvie 2014; Carmichael et al. 2016). However, important differences still exist among European countries and regions, as illustrated in Table 1 (Berardo et al. 1993; Bergstrom and Schoeni 1996; Balistreri et al. 2017). Northern countries (e.g., Sweden, Denmark) were associated with the highest mean age at marriage for both spouses in the early 1990s. At the same time, northwestern countries (France, Belgium, Ireland, and Finland, together with Lithuania) were associated with the lowest gender age gap at marriage. In the late 2010s, the latest age at marriage was observed, on average, in a more heterogeneous sample of countries of western (France), northern (Sweden, Norway) and southern (Spain, Italy) Europe. The same pattern was observed for the gender age gap, being the lowest in Ireland but also in France and Portugal. These data indicate a substantial convergence toward marriage postponement all over Europe, reducing the traditional gap in average marriage age (for both spouses) between western-northern Europe (later marriages) and southern-eastern Europe (earlier marriages).

Within this transition, Mediterranean countries were associated for a long time with traditional demographic behaviors - including marriage at younger age and a relatively high gender gap indicating social heterogamy. More recently, age at marriage in southern Europe has levelled off at the values recorded in countries of western, central and northern Europe (Gavalas et al. 2014). However, empirical studies concerning age at marriage and the related gender gap were developed more frequently for western, northern and central European countries (e.g., Oppermann 2017), with limited coverage of Mediterranean contexts (Kalmijn 2007). Demographic changes in southern Europe have been 
strongly connected with marriage postponement-with a direct influence on fertility, since most of childbearing arises inside of marriage (Rontos 2007, 2010; Lundberg et al. 2016; Salvati and Carlucci 2017). While being renewed for a relatively high fertility (Ongaro 2001), Mediterranean populations were more recently shifting toward a very low fertility compared with other European macro-regions (Oppermann 2017; Sobotka et al. 2017; Lappegård et al. 2018). Lowest-low fertility was frequently related to marriage postponement in Mediterranean countries (Rosina and Fraboni 2004; Van Bavel and Różańska-Putek 2010; Guetto and Azzolini 2015). Moreover, changes in marriage timing went hand in hand with an increased spatial variability in marriage rates (Goldstein et al. 2013; Carmichael et al. 2016; Balistreri et al. 2017), influencing demographic structures and population growth rates (Goldstein et al. 2009).

Table 1. Mean age at marriage and absolute gender gap (years) in the mean age at marriage for selected European countries, by year.

\begin{tabular}{ccccccc}
\hline \multirow{2}{*}{ Country } & \multicolumn{2}{c}{$\mathbf{1 9 9 0}^{*}$} & \multirow{2}{*}{ Gender Gap } & \multicolumn{2}{c}{ 2018** } & \multirow{2}{*}{ Gender Gap *** } \\
\cline { 2 - 3 } \cline { 5 - 6 } & Men & Women & & Men & Women & \\
\hline Austria & 27.7 & 25.2 & 2.5 & 34.2 & 31.5 & 2.7 \\
Belgium & 26.5 & 24.4 & 2.1 & 33.5 & 31.2 & 2.3 \\
Bulgaria & 24.6 & 21.5 & 3.1 & 30.6 & 27.3 & 3.3 \\
Czechia & 24.3 & 21.6 & 2.7 & 31.8 & 29.1 & 2.7 \\
Denmark & 30.5 & 27.8 & 2.7 & 34.8 & 32.4 & 2.4 \\
Finland & 28.4 & 26.3 & 2.1 & 33.9 & 31.6 & 2.3 \\
France & 28.0 & 25.9 & 2.1 & 34.9 & 32.8 & 2.1 \\
Germany & 28.2 & 25.5 & 2.7 & 34.0 & 31.2 & 2.8 \\
Greece & 29.0 & 24.9 & 4.1 & 33.4 & 30.1 & 3.3 \\
Hungary & 24.7 & 22.0 & 2.7 & 32.3 & 29.4 & 2.9 \\
Ireland & 28.7 & 26.6 & 2.1 & 33.8 & 31.9 & 1.9 \\
Italy & 28.9 & 25.9 & 3.0 & 35.0 & 32.2 & 2.8 \\
Lithuania & 24.6 & 22.7 & 1.9 & 30.5 & 27.8 & 2.7 \\
Luxembourg & 27.7 & 25.6 & 2.1 & 34.0 & 31.6 & 2.4 \\
Netherlands & 28.5 & 26.1 & 2.4 & 33.9 & 31.4 & 2.5 \\
Norway & 29.0 & 26.4 & 2.6 & 35.0 & 32.3 & 2.7 \\
Portugal & 26.4 & 24.0 & 2.4 & 32.5 & 30.7 & 1.8 \\
Romania & 25.6 & 22.4 & 3.2 & 31.0 & 27.5 & 3.5 \\
Slovenia & 26.9 & 23.9 & 3.0 & 32.9 & 30.4 & 2.5 \\
Spain & 27.8 & 25.6 & 2.2 & 35.4 & 33.2 & 2.2 \\
Sweden & 30.3 & 27.7 & 2.6 & 36.6 & 33.8 & 2.8 \\
Switzerland & 29.4 & 27.0 & 2.4 & 32.8 & 30.4 & 2.4 \\
\hline
\end{tabular}

Source: Eurostat $\left({ }^{*} 1991\right.$, in a few cases when 1990 figure was not available; ${ }^{* *} 2016$ or 2017, in a few cases when 2017 figure was not available; ${ }^{* * *}$ absolute difference (years) between average men and women age at marriage).

In these regards, Greece showed a peculiar trajectory over time, with a particularly high gender age gap at marriage declining more rapidly than in other countries of the same region, such as Spain and Italy. This transition was influenced by social factors including education and higher female employment rates, women's emancipation, but also more volatile housing markets, young unemployment, and job instability, whose effects were sometimes molded by recurrent economic stagnations (Castro Martín 1995; Bongaarts 2003; Adsera 2004; Billari and Kohler 2004; Sobotka et al. 2011; Esteve et al. 2012; Kreyenfeld et al. 2012; Zaidi and Morgan 2017). Although regarded as one of the most traditional societies in Europe, Greece has undergone important modifications in marriage patterns and trends in recent times, including alternative-mainly informal—forms of cohabitation (Gavalas et al. 2014). The evolving economic forces that have characterized regional and local contexts in Greece may reflect a generalized process of modernization influencing lifestyles, beliefs and attitudes toward marriage typical of Mediterranean societies (Zambon et al. 2017). The intrinsic match of a traditional society with a relatively rapid demographic and cultural transition toward modernization and unconventional family models, has delineated a paradigmatic case for a better comprehension of the spatial context underlying 
social homogamy in both advanced and emerging economies (Di Feliciantonio et al. 2018). For instance, the gender age gap at marriage was frequently associated with the socioeconomic polarization in urban and rural areas - a characteristic feature of population dynamics and demographic structures in Greece, shaping marriage, birth and death rates along the 20th century (Rontos et al. 2016).

To better investigate sociocultural changes and the intrinsic impact on marriage attitudes, the relationship between spatial heterogeneity in the gender age gap and the socioeconomic profile of local communities should be investigated further in such contexts. To the best of our knowledge, these aspects have been only indirectly documented for Greece (Tragaki and Bagavos 2019), contrary to other southern and western European countries (Medrano et al. 2014; Koelet and de Valk 2014; van Wissen and Heering 2014). Assuming gender gap in the age at marriage as a relevant variable depending on local contexts - and illustrating urban-rural polarizations likely being better than other demographic indicators (Hogan 1978; Oppenheimer 1988; Jones and Gubhaju 2009) — the present study investigates spatial variability in (and the influence of local context on) gender differentials in the age at marriage in Greece (Kotzamanis et al. 2017).

Space was considered an important mediator of macro- and micro-demographic dynamics, highlighting the importance of local contexts influencing individual behaviors as far as marriage and childbearing are concerned (Vitali and Billari 2017). In this line of thinking, our work definitely intervenes in the debate on space-in addition to individual behaviors, social choices and global economic determinants-as a relevant dimension in both regional demography and urban-rural sociology (Lerch 2019). Recent development in spatially explicit techniques has provided a key opportunity to examine and interpret socio-demographic phenomena-such as marriage postponement and the gender age gap at marriage-at multiple spatial and temporal scales (Muniz 2009). More specifically, spatial statistical methodologies leverage information on location (e.g., a given place or area), relative location (the relative positioning of places or areas within a study region, based on adjacency, proximity and distance metrics) and the related demographic attribute(s), allowing a comprehensive investigation of the role of space and spatial processes in marriage dynamics (Di Feliciantonio et al. 2018). To examine whether and how geographical environments directly affect outcomes such as the gender age gap at marriage, simplified statistical techniques were adopted in this study, including Moran's global and local spatial autocorrelation analysis and a geographically weighted regression. These approaches are widely used methodologies forming the basic knowledge of a spatially informed socio-demographic research (Muniz 2009; Vitali and Billari 2017; Lerch 2019).

\section{Methodology}

\subsection{Study Area}

The investigated area covers Greece $\left(301,330 \mathrm{~km}^{2}\right)$ and was partitioned into 51 administrative domains (namely prefectures or "nomarchiaka diamerismata—ex nomoi" in Greek). Exploring a time interval between 1980 and 2017 allows investigation of the gender age gap at marriage in Greece (Gavalas et al. 2014). Urban population increased up to the 1990s, being substantially stable in the following decades, with increasingly low fertility rates and aging. Total Fertility Rate decreases from 2.63 in 1951 to 1.31 in 2000, remaining at a very low level in the most recent years (1.34 between 2010 and 2018). The ageing index raised to 151 in 2017 in comparison to a rate of 24 in 1951 and 54 in 1981 (Rontos 2007 , 2020). International immigration since the late 1980s was more intense in Greece and concentrated on peri-urban districts, being progressively less intense in strictly urban areas (Rontos 2010). With the 2008 recession, higher unemployment rates at a younger age and a particularly volatile labor market influenced demographic dynamics (Gkartzios and Scott 2015), leading to marriage postponement (Rontos 2010, 2020) and reduced childbearing propensity (Salvati and Carlucci 2017). The mean age at marriage was 33 years for men and 30 years for women, increasing significantly from the figure observed, e.g., in 1961 (30 and 25 years respectively for men and women). More recent trends in Greece reflect a complex stratification of demographic patterns varying largely over space and intensifying the 
relationship between economic cycles and population dynamics (Kotzamanis et al. 2017). Economic expansion between the late 1990s and the mid-2000s led to a partial recovery in marriage and fertility rates in a context of increasing immigration from abroad (Carlucci et al. 2017). Since the late 2000s, recession was indirectly associated with marriage postponement and a further decrease of fertility, as well as an aging and a shrinking population because of a progressively lower immigration, as a consequence of the reduced attractiveness of Greek economy and job market (Salvati 2016). Recent migration flows from Asian and African countries towards Greece are not yet evaluated for their influence in present (and future) regional population dynamics.

\subsection{Data Sources and Demographic Variables}

The present study was based on spatially disaggregated statistical data released by Hellenic Statistical Authority (ELSTAT) for the whole of Greece. Spouses' age differentials at marriage (years) were derived from vital statistics between 1980 and 2017 and reporting age at first marriage for both males and females at the spatial scale of prefectures (Figure 1). The average gender gap was mapped and tabulated for selected territorial partitions resembling the urban-rural gradient in Greece: (i) the Greater Athens' area (a compact urban area with population density $>7000$ inhabitants $/ \mathrm{km}^{2}$ ), (ii) the rest of the administrative region of Attica (an originally rural region with more intense urban expansion in recent decades and population density overpassing 1000 inhabitants $/ \mathrm{km} 2$ in 2011), (iii) Salonika prefecture (a peri-urban region centered on the second largest city in Greece), and (iv) the rest of Greece (with smaller cities and prefectural head towns scattered over a rural landscape matrix). An average measure of gender differentials in the age at marriage was also calculated for marriages celebrated outside Greece by at least one spouse with Greek citizenship.

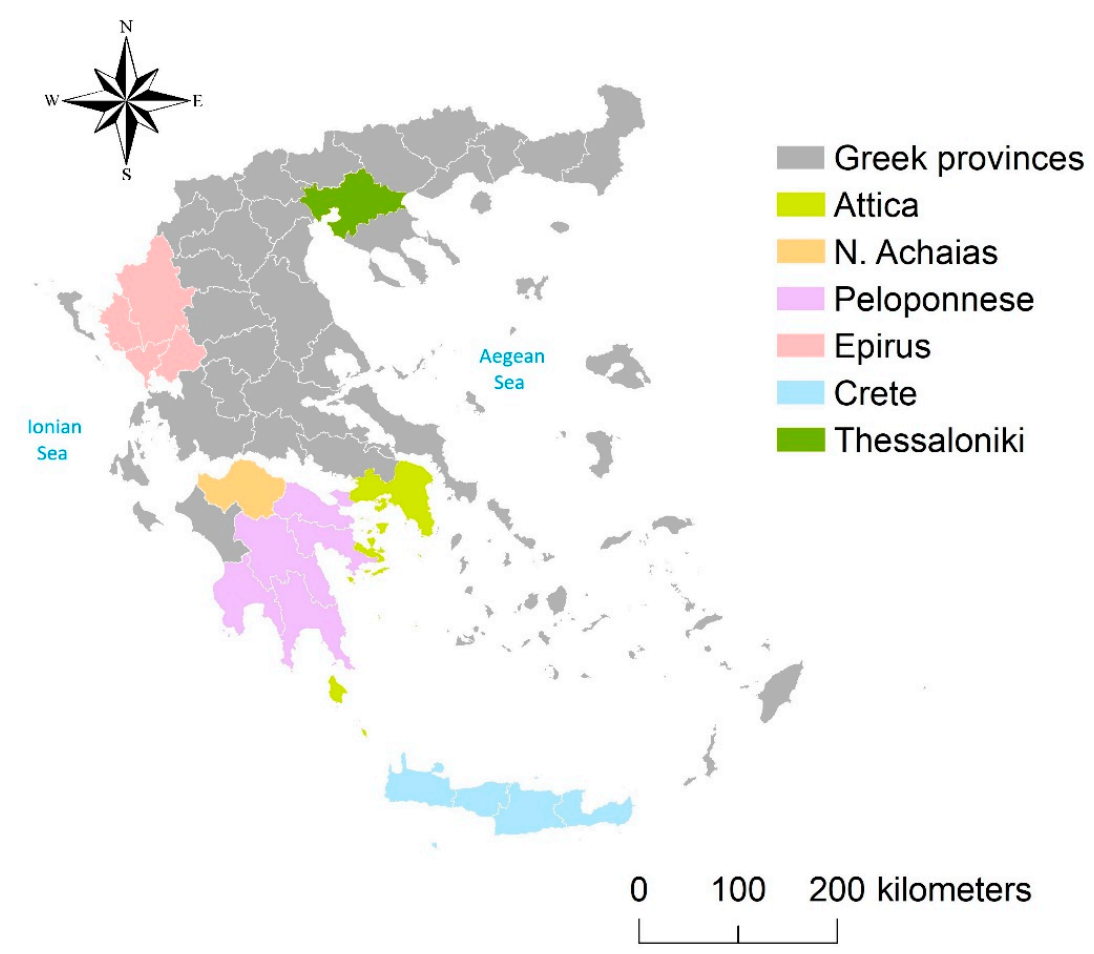

Figure 1. Map of Greek prefectures (nomarchiaka diamerismata) and other relevant locations in Greece.

\subsection{Contextual Indicators}

A total of 17 background indicators were adopted with the aim to delineate a socioeconomic profile for each Greek prefecture (Salvati 2018). Being derived from official sources (ELSTAT or Hellenic Ministry of Finance), indicators covering the most recent part of the study period and include: (i) population density (inhabitants $/ \mathrm{km}^{2}$ ) at the beginning of recession (2009), (ii) per-capita 
average income in 2009 (Euros), (iii-iv) per cent annual growth rate of gross value added over both expansion (2000-2008) and recession (2009-2016), per cent share of (v) agriculture and (vi) industry value added in total value added (both recorded in 2009), linear distances from (vii) Athens (km) and (viii) Salonika (km), (ix) proximity to the sea coast (a dummy classifying prefectures as 'inland' or 'coastal'), (x) a dummy classifying prefectures as 'tourism-specialized', (xi) road infrastructures (a dummy identifying prefectures connected with Athens and/or Salonika with at least a highway of national importance), presence of (xii) an international airport or (xiii) a state university (indicating the level of attractiveness and openness to global dynamics as well as knowledge infrastructures), as well as (xiv-xvii) natural and migration balance (\% of population growth) for two consecutive time windows representing economic expansion (2002-2009) and recession (2010-2017) in Greece.

\subsection{Statistical Analysis}

Average gender gap (years) in the age at marriage is a common demographic indicator suitable for spatial analysis (Ortega 2014). Average gender gap in Greek prefectures was mapped separately for 1980 and 2017, and annual (per cent) rate of change between 1980 and 2017 was also calculated and mapped. The regional structure of this indicator was studied using global and local Moran's indices of spatial autocorrelation separately for 1980 and 2017. Moran's indices of spatial autocorrelation are statistical tools widely used in social science (Salvati 2018). By measuring spatial autocorrelation considering simultaneously feature locations and attributes, the global Moran's index evaluates whether a specific variable displays a clustered, dispersed or random distribution over space; $z$-scores and the associated $p$-value were considered to test significant autocorrelation in a given spatial structure. The analysis was carried out separately at 6 bandwidths $(25,50,75,100,125$ and $150 \mathrm{~km})$ exploring spatial relationships from local to regional scale. Under significant $p$-values $(p<0.05)$, positive or negative $z$-scores indicate respectively a clustered or dispersed spatial distribution of the study variable.

\subsubsection{Local Moran's Index of Spatial Autocorrelation}

Local Moran's statistics were calculated with the aim to identify local clusters and spatial outliers through computation at a given spatial bandwidth selected according with the highest $z$-scores derived from the global Moran's analysis mentioned above (Salvati 2018). Local Moran's coefficients of spatial autocorrelation for each Greek prefecture were tested for significance at $p<0.001$. Significant regimes of spatial autocorrelation were identified using significant Moran's $z$-scores as follows: homogeneous districts with either (i) positive correlations (hereafter 'high-high clusters'), (ii) negative correlations ('low-low clusters'), or (iii-iv) transitional districts with heterogeneous dynamics ('high-low clusters') or ('low-high clusters'). Local heterogeneity is associated with spatial divides reflecting a (more or less steep) gradient in the studied variable (Salvati and Serra 2016).

\subsubsection{Correlation Analysis and Regression Models}

A non-parametric Spearman correlation analysis was run pairwise between the average gender gap (years) and the mean age at marriage (years) for women in Greece over 1980-2017 $(n=38$ observations) testing for significance at $p<0.05$ (Colantoni et al. 2016). Additionally, a multiple linear regression was run on standardized variables (Pili et al. 2017) with the aim to rank the importance of contextual indicators explaining spatial variability of the gender gap in the mean age at marriage across Greek prefectures (Duvernoy et al. 2018). A forward stepwise approach was adopted considering gender gap (years) for 2017 as the dependent variable, and the 17 indicators illustrated in Section 2.3 as predictors. Indicators were included in each model based on the respective Fisher-Snedecor $F$ test $(p$-level $<0.01)$. Results take account of slope coefficient estimates and the associated significance level based on Student $t$ statistics at $p<0.05$ (Zitti et al. 2015). The goodness-of-fit of each regression model was assessed using adjusted $\mathrm{R}^{2}$ and tested for significance (against the null hypothesis of a non-significant model) through a Fisher-Snedecor $F$ statistic $(p<0.001)$. 
Local-scale variability in the relationship between gender gap in the age at marriage (dependent variable) and variables assessing the background socioeconomic context was analyzed through a spatially explicit regression model, quantifying (and ranking) the impact of relevant predictors over Greek prefectures. A geographically weighted regression (GWR) approach was adopted with the aim to identify local predictors of the gender gap in the mean age at marriage at the spatial level of Greek prefectures. The specification of a basic GWR model for each location $\mathrm{s}=1, \ldots, n$, was:

$$
\mathrm{Y}(\mathrm{s})=\mathrm{X}(\mathrm{s}) \mathrm{B}(\mathrm{s})+\mathrm{e}(\mathrm{s})
$$

where $\mathrm{Y}(\mathrm{s})$ is the dependent variable at location $\mathrm{s}, \mathrm{X}(\mathrm{s})$ is the vector of predictors at location $\mathrm{s}$ (including significant variables identified in the step-wise regression model described above), B(s) is the column vector of regression coefficients at location $\mathrm{s}$, and $\mathrm{e}(\mathrm{s})$ is the random error at location $\mathrm{s}$ (Fotheringham et al. 2003). As a result, GWR provides (i) a global estimate of the model's goodness of fit (adjusted $\mathrm{R}^{2}$ ) and (ii) local estimates of regression parameters (predictor's coefficients, local $\mathrm{R}^{2}$, intercept and standard residuals).

\section{Results}

\subsection{Descriptive Statistics}

A continuous increase in the age at marriage (6.2 and 8.0 years respectively for males and females) was observed in Greece between 1980 and 2017. Differences in the mean age at marriage between men and women decreased substantially from 5.3 years (1980) to 3.5 years (Figure 2). Decline in the gender gap slowed down at the beginning of the economic crisis (2009). Age differentials between spouses decreased with the rise of mean age at marriage of women (Spearman rank correlation $r_{\mathrm{s}}=-0.7$, $p<0.05, n=38$ ). Absolute differences and percent change over time in the target variable were reported in Table 2 for selected districts in Greece. Results outlined a marked variability depending on the regional context. Urban-rural divides in the mean age at marriage were documented for both males and females.

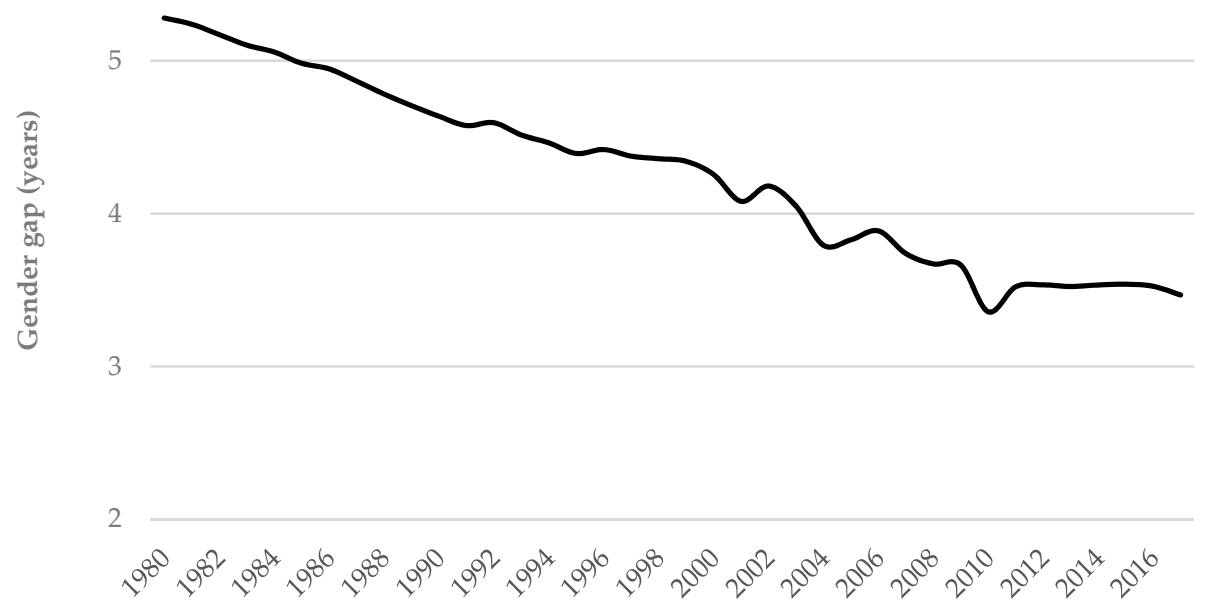

Figure 2. Gender gap (males—females) in the mean age at marriage (years) in Greece, 1980-2017.

Variability in the gender age gap at marriage reduced between 1980 (coefficient of variation across Greek prefectures: 17.1\%) and 2017 (14.9\%). The corresponding value of gender age gap for marriages celebrated outside Greece by at least one non-resident spouse with Greek citizenship was lower for both 1980 and 2017. At the beginning of the study period, gender age gap was particularly high in 
rural areas surrounding Athens ('rest of Attica': 5.7 years) and in other Greek prefectures apart from Athens and Salonika ('rest of Greece': 5.6 years), being lower in both Athens and Salonika (respectively 4.8 and 4.7 years). In 2017, the population residing in the Greater Athens' area displayed the lowest gender age gap in Greece (3.1 years); Salonika and the rest of Attica followed respectively with 3.3 and 3.4 years. Divergences with the rest of Greece (3.7 years) were rather low compared with the beginning of the study period.

Table 2. Gender gap (years) in the mean age at marriage for selected regions of Greece, by year ( ${ }^{*}$ marriages celebrated abroad by at least one spouse with Greek citizenship).

\begin{tabular}{cccc}
\hline Region & $\mathbf{1 9 8 0}$ & $\mathbf{2 0 1 7}$ & \% Change \\
\hline Greater Athens' area & 4.8 & 3.1 & -1.0 \\
Rest of Attica & 5.7 & 3.4 & -1.1 \\
Salonika province & 4.7 & 3.3 & -0.8 \\
Rest of Greece & 5.6 & 3.7 & -0.9 \\
Greece, total & 5.3 & 3.5 & -0.9 \\
Abroad * & 4.9 & 2.7 & -1.2 \\
\hline
\end{tabular}

Maps illustrating the gender age gap at marriage for each prefecture (Figure 3) indicate, at the beginning of the study period, a substantial disparity between rural districts in central and southern Greece (Peloponnese, Aegean islands and part of Crete), with a gender age gap above 6 years on average, and rural regions in northern Greece, with a gender gap between 5 and 6 years. Values below 4 years were observed in areas surrounding Athens and Salonika. At the end of the study period, the highest gender age gap (above 5 years) was found in few marginal, inland prefectures of central Greece. On average, the gender age gap was below 4 years in urban areas and accessible, rural districts throughout Greece.
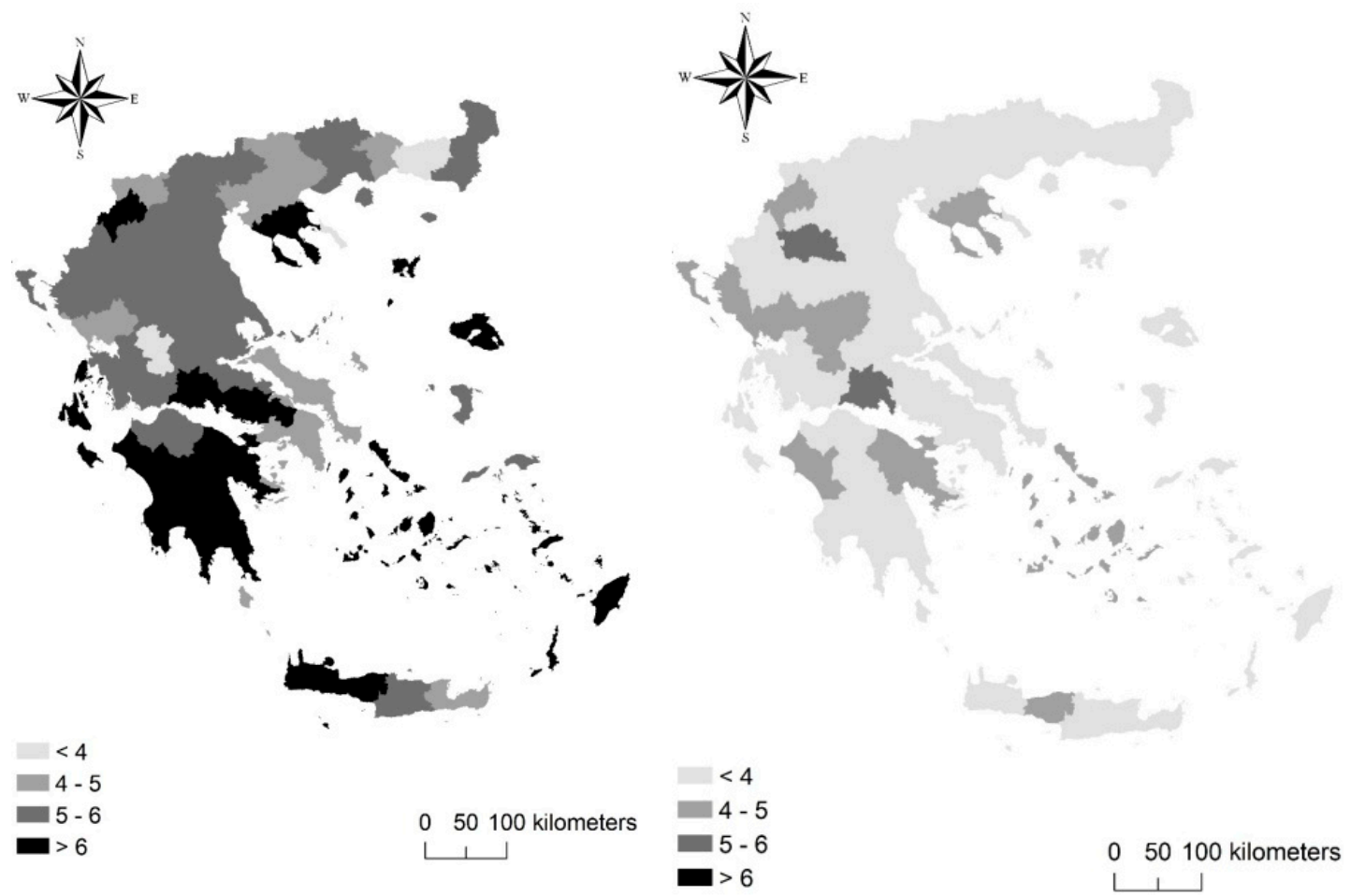

(a)

(b)

Figure 3. Cont. 


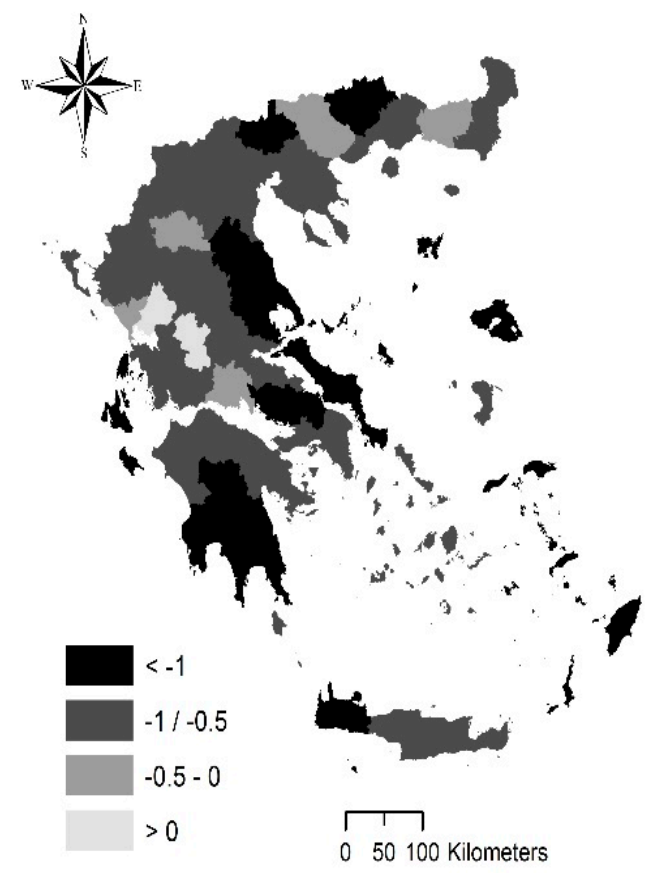

(c)

Figure 3. Gender gap (males—females) in the mean age at marriage (years) in Greece: 1980 (a), 2017 (b) and annual (per cent) rate of change in gender age differentials over time (c).

\subsection{Spatial Autocorrelation Analysis}

Using six bandwidths ranging from 25 to $150 \mathrm{~km}$, global Moran's coefficients of spatial autocorrelation showed differences between years for the study variable (Table 3). Spatial autocorrelation in the gender age gap was more intense in 1980 compared with 2017, likely indicating a territorial polarization reduced over time. Highly significant autocorrelation coefficients were observed for bandwidths $>50 \mathrm{~km}$ in 1980 and for bandwidths $>100 \mathrm{~km}$ in 2017.

Table 3. Global Moran's spatial autocorrelation index (z-score) of the gender gap (years) in mean age at marriage by year and bandwidth $(\mathrm{km})$; significant correlations at ${ }^{*} p<0.05$ and ${ }^{* *} p<0.01$.

\begin{tabular}{ccc}
\hline Bandwidth (km) & $\mathbf{1 9 8 0}$ & $\mathbf{2 0 1 7}$ \\
\hline 25 & 0.73 & 1.40 \\
50 & 1.10 & 1.67 \\
75 & $3.58^{* *}$ & 1.98 \\
100 & $3.222^{* *}$ & 2.04 \\
125 & $3.24^{* *}$ & $2.52^{*}$ \\
150 & $3.35^{* *}$ & $2.72^{*}$ \\
\hline
\end{tabular}

Maps illustrating significant local Moran's coefficients of spatial autocorrelation (Figure 4) outline spatial clusters for the gender gap in the mean age at marriage in Greece. The impressive divide in high-high (Peloponnese) and low-low (eastern Macedonia and Trace) clusters observed in 1980 reduced substantially in 2017, when only a few prefectures in central Greece were classified as a 'high-high' cluster. Taken together, the results from the global and local Moran's coefficients indicate spatial polarization in urban and rural areas at the beginning of the study period and a milder divide at the end of the study period, better outlining core regions (urban and accessible, rural areas) from more peripheral districts (mountainous, inland and less accessible, low-density areas). 


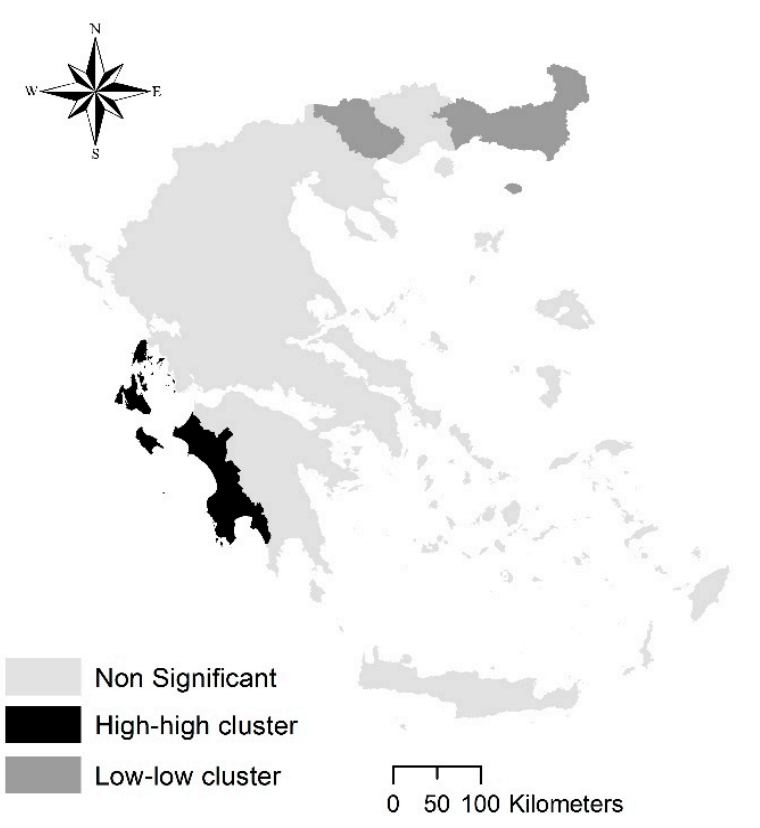

(a)

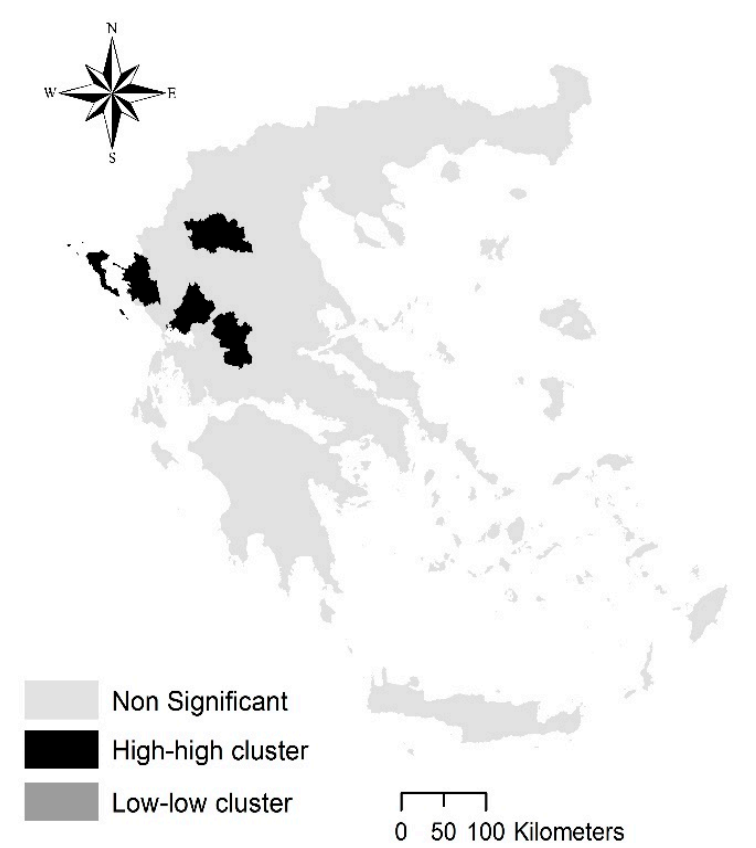

(b)

Figure 4. Local Moran's spatial autocorrelation index ( $z$-score) of the gender gap (years) in the mean age at marriage by year and bandwidth ( $\mathrm{km}$ ); significant coefficients (high-high or low-low) at $p<0.05$ (1980: (a); 2017: (b)).

\subsection{Regression Models}

To identify contextual factors influencing the mean age at marriage in Greek prefectures, a global Ordinary Least Square regression model was run considering the average gender age gap at the latest year (2017) as dependent variable and 17 background variables (Section 2.3) as independent predictors. Forward stepwise regression selected 3 significant variables in a linear model with adjusted $R^{2}$ around 0.3 (Table 4): industrial specialization and per cent rate of income growth during economic expansion (2000-2008) were the two predictors with the highest (negative) impact on the gender gap in the mean age at marriage across Greek prefectures (slope $=-0.41$ in both cases). The presence of a public university contributed to reduce the gender age gap at marriage (slope $=-0.31$ ).

Table 4. Forward step-wise multiple regression with the gender gap (years) in the mean age at marriage (2017) as dependent variable and contextual indicators as predictors (Adjusted $\mathrm{R}^{2}=0.274 ; \mathrm{F}_{(3,47)}=7.28$; $p<0.0004$; Std. Error of estimate $=0.85$ ).

\begin{tabular}{ccccc}
\hline Variable & Slope & Std. Err. & $\boldsymbol{t}(\mathbf{4 7 )}$ & $\boldsymbol{p}$-Value \\
\hline University $^{*}$ & -0.318 & 0.128 & -2.487 & 0.016 \\
Industry $^{* *}$ & -0.413 & 0.137 & -2.999 & 0.004 \\
Income growth $^{* * *}$ & -0.412 & 0.143 & -2.870 & 0.006 \\
\hline
\end{tabular}

* a dummy variable indicating the presence of a state university at province level, ${ }^{* *}$ per cent share of the industrial value added in total value added, ${ }^{* * *}$ annual per-cent income growth, 2000-2008.

Figure 5 illustrates the results of a geographically weighted regression with the gender age gap at marriage as the dependent variable. The model's goodness-of-fit increased markedly (global $R^{2}=0.36$ ). A marked goodness-of-fit of the local model for gender age gap at marriage was observed in rural regions of southern Greece, mainly Peloponnese and Crete (local $\mathrm{R}^{2}$ systematically higher than 0.6 ), where the largest age gap was observed at the beginning of the study period. The 'university' predictor negatively impacted gender age gap in western Greece. Conversely, industrial specialization and income growth during economic expansion display a more intense (negative) impact on the dependent 
variable in central and eastern Greece (Attica and industrial regions around Athens, such as Viotia, Korinthias and Argolida, as well as Aegean islands and Crete).
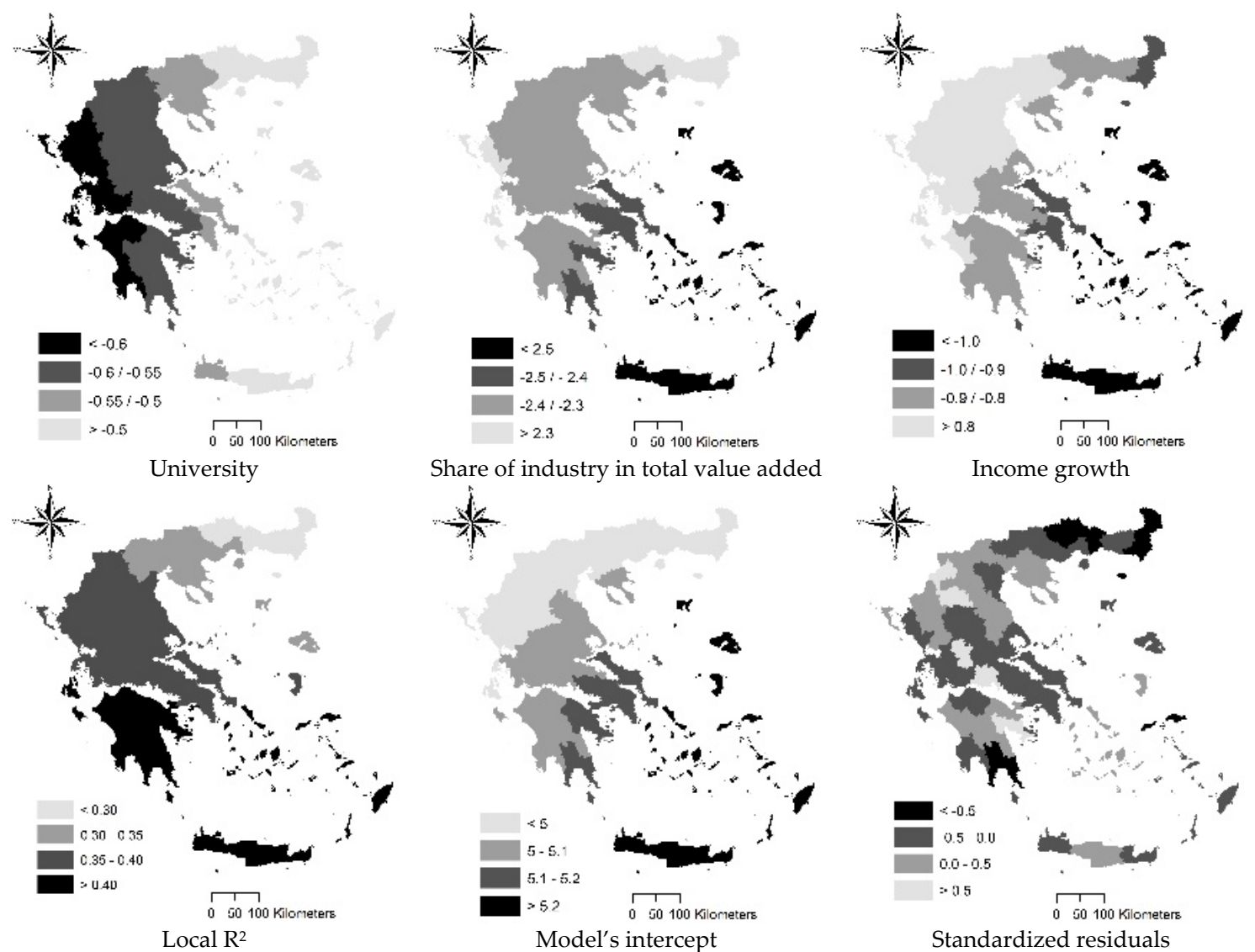

Figure 5. Geographically Weighted Regression with the gender gap (years) in the mean age at marriage (2017) as dependent variable and contextual variables as predictors.

\section{Discussion}

Women's emancipation, boundaryless social networks and communication led to new cultural values and beliefs, individual behaviors and lifestyles shaping marriage dynamics and fertility patterns (Coale and McNeil 1972; Hernes 1972; Oppenheimer 1988). Assuming space as a key factor influencing social attitudes and demographic behaviors (Malhotra 1997; Dennison and Ogilvie 2014; Lundberg et al. 2016), a refined analysis of the geographical variability in the age at marriage was revealed of great interest in social sciences (Zhang et al. 2008). This is particularly true when geographic variability in vital statistics is examined over a sufficiently long-time interval, encompassing demographic transitions and economic cycles (Wu and Balakrishnan 1992; South 1993; Otta et al. 1999; Todd et al. 2005; Rontos 2010). The results of the explicit spatial models adopted in this study quantify the impact of space - as a relevant dimension in regional demography - in respect to individual behaviors, social choices and global economic drivers of change (Di Feliciantonio et al. 2018). Marriage postponement was considered a relevant factor at the base of demographic transition in advanced economies (Caldwell et al. 1983; Balistreri et al. 2017; Lappegård et al. 2018), causing (apparent or latent) impacts on fertility and being in turn influenced by intrinsic socioeconomic conditions and spatially explicit factors (Casterline et al. 1986; Carmichael 2011; Carmichael et al. 2016). As a result of a long demographic transition, age at marriage for women is now particularly high in southern Europe and aligned to the average values recorded in western and northern Europe (Kalmijn 2007) — the regions with the highest mean age at marriage in the world-having overpassed both central Europe (on average, 27 years) and eastern Europe (22 years). In line with such dynamics, age at marriage for women was increasing 
rapidly over the last three decades in Greece, although maintaining lower than those observed e.g., in Italy or Spain.

The results of our study also indicate a progressive reduction in the gender age gap at marriage in most of Greek prefectures. However, a clear distinction in urban and rural areas was observed during the 1980s, reflecting social homogamy in more open communities and social heterogamy in more peripheral and less accessible districts. In rural areas, the mean age at marriage was relatively low compared with urban areas, with a particularly intense gender gap. Marriage postponement observed in more recent decades led to a marked increase in the mean age at marriage for both spouses (Rontos 2010). Mean age at marriage for women increased more rapidly than for men, determining a progressive-but spatially asymmetric - decrease in the gender age gap at marriage. As a matter of fact, decline in the gender age gap was more evident in accessible and highly populated rural areas (Gavalas et al. 2014). These dynamics levelled off the inherent spatial divides observed in the early 1980s, resulting in a more homogeneous age at marriage for both spouses at the end of the study period.

Marriage postponement was attributed to a mix of socioeconomic forces interacting over both long-time intervals (higher education, skills, and emancipation of women) and the short-run (economic shocks, including the 2008 recession). Convergence toward spatial homogenization in marriage postponement trends observed in Greece over the last four decades evidenced a social transition toward modernity and globalization in line with the background assumptions of this study (Vera et al. 1985; Tucker and Mitchell-Kernan 1990; Yan 2015; Crandall et al. 2016). As a matter of fact, Moran's spatial autocorrelation analysis revealed a polarized spatial structure of the gender age gap at the beginning of the study period and a more heterogeneous structure at the end of the study period. The gender age gap at marriage had a significant spatial correlation, more intense on a regional scale than on a district scale. These results highlight how, especially in the early 1980s, urban areas were strongly differentiated from rural ones. In the late 2010s, spatial correlation was moderate at all observation scales, highlighting less intense disparities along the urban-rural gradient. Locally, the Moran index highlighted the emergence of latent geographic gradients, such as the east-west gradient in Greece (more accessible and densely populated prefectures located in eastern Greece).

While in the past urban populations were characterized by more emancipated behaviors, a higher level of education, better working position and a higher economic independence than rural populations, the role of women changed significantly in recent decades, with a progressive convergence between rural and urban societies (Myers and Hastings 1995). Less 'traditional' attitudes toward marriage were observed together with a particularly active role of women in the job market spreading all over the country-more rapidly in accessible rural districts (Gavalas et al. 2014). With globalization of values, beliefs and attitudes (Berardo et al. 1993), such processes are supposed to lead to a progressive neutralization of space as a factor molding social dynamics (Rontos 2020), with a progressive convergence in demographic behaviors. In other words, the empirical results presented here confirm the working hypothesis of our study, since the spreading of social homogamy across Greek prefectures may perfectly reflect the underlying social change in most local communities, altering the traditional urban-rural divide and bringing to an even more polarized society with large parts of the country being socially open and a small part remaining still anchored to traditional social models (Rontos et al. 2016). In these regards, the diffusion of social homogamy during the study period seems to be still heterogeneous over space, with the emergence of rural communities less permeable to social change even in more accessible districts close to urban regions.

The results of the spatial regression contribute to define the socioeconomic profile of 'permeable' or 'resistant' communities to social change, as reflected by local trends in social homogamy. Highly variable $R^{2}$ coefficients of spatial models indicate the different influence of territorial factors on the attitude toward social homogamy in Greek prefectures, demonstrating that local context is an important dimension shaping the gender age gap in traditional societies. Regression analysis for 2017 indicates industrial specialization, wealth, and the presence of a public university, as the most relevant variables characterizing local contexts with a lower gender age gap at marriage. Impact of 
industrial specialization was higher in central Greece, especially in industrial regions such as Attica, Viotia, Korinthias and Argolida, as well as in eastern Greece, and particularly in Crete and in the Aegean islands. These prefectures include rural districts where industrial concentration and tourism specialization created favorable conditions for local development in recent decades (Salvati 2016). The influence of income growth on the gender age gap at marriage was more evident in coastal districts of eastern Greece and less evident in more disadvantaged and less accessible rural districts of western Greece. Finally, the impact of the third predictor (university) was more evident in western Greece, likely indicating different local contexts associated with marriage postponement. Based on these results, reduced age differentials at marriage were associated with wealthy and more accessible contexts with higher participation of women to the job market in eastern Greece, and with a higher level of education-possibly leading to women emancipation and less traditional attitudes toward marriage-in western Greece.

The progressive shift from a marked age divide in urban and rural areas to less intense age differentials at marriage associated with a generalized marriage postponement in urban and more dynamic rural areas, led to a negative impact on local fertility rates (Tragaki and Bagavos 2019). Such transition, observed between 1980 and 2017, reflects the spreading of 'modernized' attitudes and beliefs toward marriage well beyond the urban-rural gradient (Rontos 2007, 2010). Populations living in rural, accessible and economically dynamic lowland districts displayed similar behaviors with urban populations, distinguishing from a few economically marginal (and mostly mountainous) peripheral areas characterized by traditional demographic patterns, where traditional family structures and a more patriarchal society still represent the dominant rule (Salvati 2016). Presence of a public university, per cent share of industry in total value added and income growth during economic expansion were the most relevant predictors of the gender age gap at marriage in Greece, all exerting a negative impact on the dependent variable. However, the impact of these predictors was spatially heterogeneous, since the presence of a public university was more negatively associated with the gender age gap at marriage in prefectures of the Ionian (western) side of Greece. A specular pattern was observed for the last two predictors.

In contrast with the dominant trend of marriage postponement in Greece (Kotzamanis et al. 2017), decline in the gender age gap slowed down since the beginning of the economic crisis (2008), evidencing a latent role of recession in altering long-term demographic patterns (Salvati 2016). Such dynamics should be investigated further in the next years, when more solid quantitative information on demographic trends and local job markets will be available from the population census. In these regards, the possible influence of the 2008 recession in specific aspects of population dynamics and social behaviors (Tragaki and Bagavos 2019), can be ascertained using mixed analysis' frameworks based on integration of micro- and macro-approaches. Multilevel analysis has demonstrated to contribute effectively to a better comprehension of socio-demographic transitions, delineating future population scenarios more precisely.

\section{Conclusions}

The empirical results of this study demonstrate how space influences socio-demographic change as far as marriage timing is concerned. In this regard, a multilevel analysis linking a spatially varying propensity to marriage and childbearing with individual perspectives, socioeconomic background, cultural values and beliefs, contributes to improving the predictive power of theoretical and empirical approaches that investigate the recent evolution of family models. At the macro-scale, the results of this analysis suggest that the spatial diffusion of social change in economically disadvantaged areas is influenced by the emergence of 'permeable' and 'resistant' local communities with a characteristic socioeconomic profile, well beyond the traditional polarization in urban and rural districts. In other words, space becomes an important mediator of gender power dynamics, evidencing the increasing heterogeneity and fragmentation of social processes and the related demographic behaviors at the local community scale. At the micro-scale, (retrospective) interviews with spouses aimed at clarifying the 
intrinsic motivation at the base of social homogamy seem to provide additional information supporting (or problematizing) the empirical findings of a quantitative analysis based on official statistics. Integration of micro- and macro-scale approaches may finally elucidate latent patterns identified through a spatially explicit analysis of social processes based on appropriate demographic indicators.

Author Contributions: Conceptualization, L.S. and K.R.; methodology, L.S.; software, L.S.; validation, L.S. and K.R.; formal analysis, L.S.; investigation, K.R.; resources, L.S.; data curation, L.S.; writing-original draft preparation, L.S.; writing-review and editing, K.R.; visualization, L.S.; supervision, K.R.; project administration, K.R.; funding acquisition, L.S. All authors have read and agreed to the published version of the manuscript.

Funding: This research received no external funding.

Conflicts of Interest: The authors declare no conflicts of interest.

\section{References}

Adsera, Alicia. 2004. Changing fertility rates in developed countries. The impact of labor market institutions. Journal of Population Economics 17: 17-43. [CrossRef]

Atkinson, Maxine, and B. L. Glass. 1985. Marital age heterogamy and homogamy, 1900 to 1980. Journal of Marriage and the Family, 685-91. [CrossRef]

Balbo, Nicoletta, F. C. Billari, and M. Mills. 2013. Fertility in advanced societies: A review of research. European Journal of Population 29: 1-38. [CrossRef] [PubMed]

Balistreri, Kelly Stamper, Kara Joyner, and Grace Kao. 2017. Trading Youth for Citizenship? The Spousal Age Gap in Cross-Border Marriages. Population and Development Review 43: 443-66. [CrossRef]

Berardo, Felix M., Jeffrey Appel, and Donna H. Berardo. 1993. Age dissimilar marriages: Review and assessment. Journal of Aging Studies 7: 93-106. [CrossRef]

Bergstrom, Ted, and Robert F. Schoeni. 1996. Income prospects and age-at-marriage. Journal of Population Economics 9: 115-30. [CrossRef]

Bijak, Jakub, J. Hilton, E. Silverman, and V. D. Cao. 2013. Reforming the wedding ring: Exploring a semi-artificial model of population for the United Kingdom with Gaussian process emulators. Demographic Research 29: 729-66. [CrossRef]

Billari, Francesco C. 2000. Searching for mates using 'fast and frugal' heuristics: A demographic perspective. Advances in Complex Systems 3: 53-65. [CrossRef]

Billari, Francesco C. 2015. Integrating macro-and micro-level approaches in the explanation of population change. Population Studies 69: 11-20. [CrossRef]

Billari, Francesco, and Hans-Peter Kohler. 2004. Patterns of low and lowest-low fertility in Europe. Population Studies 58: 161-76. [CrossRef]

Billari, Francesco C., A. Prskawetz, B. Aparicio Diaz, and T. Fent. 2007. The 'wedding-ring': An agent-based marriage model based on social interaction. Demographic Research 17: 59-82. [CrossRef]

Blossfeld, Hans-Peter. 2009. Educational assortative marriage in comparative perspective. Annual Review of Sociology 35: 513-30. [CrossRef]

Blue, Laura, and Thomas J. Espenshade. 2011. Population momentum across the demographic transition. Population and Development Review 37: 721-47. [CrossRef] [PubMed]

Bongaarts, John. 2003. Completing the Fertility Transition in the Developing World: The Role of Educational Differences and Fertility Preferences. Population Studies 57: 321-35. [CrossRef]

Bozon, Michel. 1991. Women and the age gap between spouses: An accepted domination? Population, 113-48.

Bumpass, Larry. 1969. Age at marriage as a variable in socio-economic differentials in fertility. Demography 6: 45-54. [CrossRef]

Burgess, Ernest W., and Paul Wallin. 1943. Homogamy in social characteristics. American Journal of Sociology 49: 109-124. [CrossRef]

Bytheway, William R. 1981. The variation with age of age differences in marriage. Journal of Marriage and the Family, 923-27. [CrossRef]

Caldwell, John C., Palli Hanumantha Reddy, and Pat Caldwell. 1983. The causes of marriage change in South India. Population Studies 37: 343-61. [CrossRef] 
Carlucci, Margherita, Efstathios Grigoriadis, Kostas Rontos, and Luca Salvati. 2017. Revisiting a hegemonic concept: Long-term 'Mediterranean urbanization' in between city re-polarization and metropolitan decline. Applied Spatial Analysis and Policy 10: 347-62. [CrossRef]

Carmichael, Sarah. 2011. Marriage and power: Age at first marriage and spousal age gap in lesser developed countries. The History of the Family 16: 416-36. [CrossRef]

Carmichael, Sarah G., A. de Pleijt, J. L. Van Zanden, and T. De Moor. 2016. The European marriage pattern and its measurement. The Journal of Economic History 76: 196-204. [CrossRef]

Casterline, John B., Lindy Williams, and Peter McDonald. 1986. The age difference between spouses: Variations among developing countries. Population Studies 40: 353-74. [CrossRef]

Castro Martín, Teresa. 1995. Women's Education and Fertility: Results from 26 Demographic and Health Surveys. Studies in Family Planning 26: 187-202. [CrossRef] [PubMed]

Coale, Ansley J., and Donald R. McNeil. 1972. The distribution by age of the frequency of first marriage in a female cohort. Journal of the American Statistical Association 67: 743-49. [CrossRef]

Coale, Ansley, and James Trussell. 1996. The development and use of demographic models. Population Studies 50: 469-84. [CrossRef]

Colantoni, Andrea, Efstathios Grigoriadis, Adele Sateriano, Giuseppe Venanzoni, and Luca Salvati. 2016. Cities as selective land predators? A lesson on urban growth, deregulated planning and sprawl containment. Science of the Total Environment 545: 329-39. [CrossRef]

Crandall, AliceAnn, C. VanderEnde, Y. F. Cheong, S. Dodell, and K. M. Yount. 2016. Women's age at first marriage and postmarital agency in Egypt. Social Science Research 57: 148-60. [CrossRef]

Dennison, Tracy, and Sheilagh Ogilvie. 2014. Does the European marriage pattern explain economic growth? The Journal of Economic History 74: 651-93. [CrossRef]

Di Feliciantonio, Cesare, Luca Salvati, Efthymia Sarantakou, and Kostas Rontos. 2018. Class diversification, economic growth and urban sprawl: evidences from a pre-crisis European city. Quality E Quantity 52: 1501-22.

Medrano, Juan Díez, C. Contina, A. Safranoff, and I. Castro-Martín. 2014. Euromarriages in Spain: Recent trends and patterns in the context of European integration. Population Space and Place 20: 157-76. [CrossRef]

Duvernoy, Isabelle, Ilaria Zambon, Adele Sateriano, and Luca Salvati. 2018. Pictures from the other side of the fringe: Urban growth and peri-urban agriculture in a post-industrial city (Toulouse, France). Journal of Rural Studies 57: 25-35. [CrossRef]

England, Paula, and Elizabeth Aura McClintock. 2009. The gendered double standard of aging in US marriage markets. Population and Development Review 35: 797-816. [CrossRef]

Esteve, Albert, J. Spijker, T. Riffe, and J. García. 2012. Spousal and parental roles among female student populations in 55 low-and middle-income countries. Vienna Yearbook of Population Research 10: 77-94. [CrossRef]

Fotheringham, A. Stewart, Chris Brunsdon, and Martin Charlton. 2003. Geographically Weighted Regression: The Analysis of Spatially Varying Relationships. London: Wiley.

Gavalas, Vasilis S., Kostas Rontos, and Luca Salvati. 2014. Who becomes an unwed mother in Greece? Socio-Demographic and Geographical aspects of an emerging phenomenon. Population, Space and Place 20: 250-63. [CrossRef]

Gkartzios, Menelaos, and Karen Scott. 2015. A cultural panic in the province? Counterurban mobilities, creativity, and crisis in Greece. Population, Space and Place 21: 843-55. [CrossRef]

Goldstein, Joshua R., Tomáš Sobotka, and Aiva Jasilioniene. 2009. The end of lowest-low fertility? Population and Development Review 35: 663-99. [CrossRef]

Goldstein, Joshua R., M. Kreyenfeld, A. Jasilioniene, Ö. Karaman, and D. Deniz. 2013. Fertility reactions to the Great Recession in Europe: Recent evidence from order-specific data. Demographic Research 29: 85-104. [CrossRef]

Guetto, Raffaele, and Davide Azzolini. 2015. An empirical study of status exchange through migrant/native marriages in Italy. Journal of Ethnic and Migration Studies 41: 2149-72. [CrossRef]

Haandrikman, Karen. 2014. Binational marriages in Sweden: Is there an EU effect? Population Space and Place 20: 177-99. [CrossRef]

Haandrikman, Karen, C. Harmsen, L. J. G. van Wissen, and I. Hutter. 2008. Geography matters: Patterns of spatial homogamy in the Netherlands. Population Space and Place 14: 387-405. [CrossRef]

Hernes, Gudmund. 1972. The process of entry into first marriage. American Sociological Review 37: $173-82$. [CrossRef] 
Hogan, Dennis P. 1978. The effects of demographic factors, family background, and early job achievement on age at marriage. Demography 15: 161-75. [CrossRef] [PubMed]

Hong, Ying. 2006. Marital decision making and the timing of first birth in rural China before the 1990s. Population Studies 60: 329-41. [CrossRef]

Islam, M. Nurul, and Ashraf U. Ahmed. 1998. Age at first marriage and its determinants in Bangladesh. Asian and Pacific Population Journal 13: 73-92. [CrossRef]

Johansson, Annika, H. T. Hoa, N. T. Lap, V. Diwan, and B. Ericksson. 1996. Population policies and reproductive patterns in Vietnam. Lancet 347: 1529-32. [CrossRef]

Jones, Gavin W., and Bina Gubhaju. 2009. Factors influencing changes in mean age at first marriage and proportions never marrying in the low-fertility countries of East and Southeast Asia. Asian Population Studies 5: 237-65. [CrossRef]

Kalmijn, Matthijs. 2007. Explaining cross-national differences in marriage, cohabitation, and divorce in Europe 1990-2000. Population Studies 61: 243-63. [CrossRef]

Kiernan, Kathleen E. 1988. The British family: Contemporary trends and issues. Journal of Family Issues 9: 298-316. [CrossRef]

Koelet, Suzana, and Helga AG de Valk. 2014. European liaisons? A study on European bi-national marriages in Belgium. Population Space and Place 20: 110-25. [CrossRef]

Kotzamanis, Byron, Pavlos Baltas, and Anastasia Kostaki. 2017. The Trend of Period Fertility in Greece and Its Changes during the Current Economic Recession. Population Review 56. [CrossRef]

Kreyenfeld, Michaela, Gunnar Andersson, and Ariane Pailhé. 2012. Economic Uncertainty and Family Dynamics in Europe. Demographic Research 27: 835-52. [CrossRef]

Kulu, Hill. 2011. Spatial variation in divorce and separation: Compositional or contextual effects? Population Space and Place 18: 1-15. [CrossRef]

Lappegård, Trude, Sebastian Klüsener, and Daniele Vignoli. 2018. Why are marriage and family formation increasingly disconnected across Europe? A multilevel perspective on existing theories. Population, Space and Place 24: e2088. [CrossRef]

Lee, Ronald. 2003. The demographic transition: Three centuries of fundamental change. Journal of Economic Perspectives 17: 167-90. [CrossRef]

Lee, Ronald Demos, and David Sven Reher. 2001. Demographic Transition and Its Consequences. Population and Development Review 37: 1-275. [CrossRef]

Lerch, Mathias. 2019. Regional variations in the rural-urban fertility gradients in global South. PLoS ONE, 14. [CrossRef]

Lesthaeghe, Ron. 1983. A century of demographic and cultural change in Western Europe: An exploration of underlying dimensions. Population and Development Review 19: 411-35. [CrossRef]

Lofstedt, Paul, G. Ghilagaber, L. Shusheng, and A. Johansson. 2005. Changes in marriage age and first birth interval in Huaning County, Yunnan Province, P. R. China. Southeast Asian Journal of Tropical Medicine and Public Health 36: 1329-38.

Lundberg, Shelly, Robert A. Pollak, and Jenna Stearns. 2016. Family inequality: Diverging patterns in marriage, cohabitation, and childbearing. Journal of Economic Perspectives 30: 79-102. [CrossRef]

Malhotra, Anju. 1997. Gender and the timing of marriage: Rural-urban differences in Java. Journal of Marriage and the Family 59: 434-50. [CrossRef]

Martin, Teresa Castro. 1992. Delayed childbearing in contemporary Spain: Trends and differentials. European Journal of Population 8: 217-46. [CrossRef] [PubMed]

Morgan, S. Philip, and Miles G. Taylor. 2006. Low fertility at the turn of the twenty-first century. Annual Review of Sociology 32: 375-99. [CrossRef] [PubMed]

Morsa, Jean. 1985. What is the situation concerning Belgian fertility? Population. Famille 57: 41-60.

$\mathrm{Mu}$, Zheng, and Yu Xie. 2014. Marital age homogamy in China: A reversal of trend in the reform era? Social Science Research 44: 141-57. [CrossRef] [PubMed]

Muniz, Jeronimo O. 2009. Spatial dependence and heterogeneity in ten years of fertility decline in Brazil. Population Review 48: 32-65.

Myers, Scott M., and Donald W. Hastings. 1995. Convergence in rural-urban patterns of nuptiality and mortality: A life table update. Sociological Spectrum 15: 227-56. [CrossRef] [PubMed] 
Neels, Karel, and David De Wachter. 2010. Postponement and recuperation of Belgian fertility: How are they related to rising female educational attainment. Vienna Yearbook of Population Research 8: 77-106. [CrossRef]

Nguyen, Huu Minh. 1997. Age at first marriage in Viet Nam: Patterns and determinants. Asian and Pacific Population Journal 12: 49-74.

Ongaro, Fausta. 2001. Transition to Adulthood in Italy. Edited by M. Corijn and E. Klijzing. Translated by Adult Hood in Europe. Dordrecht: Kluwer Academic, pp. 173-207.

Oppenheimer, Valerie K. 1988. A theory of marriage timing: Assortative mating under varying degrees of uncertainty. American Journal of Sociology 94: 563-91. [CrossRef]

Oppermann, Anja. 2017. Educational field and fertility in western Germany: An analysis of women born between 1955 and 1959. Vienna Yearbook of Population Research 15: 239-67. [CrossRef]

Ortega, Jose Antonio. 2014. A characterization of world union patterns at the national and regional level. Population Research and Policy Review 33: 161-88. [CrossRef]

Otta, Emma, Renato da Silva Queiroz, Lucila de Sousa Campos, Monika W. D. da Silva, and Mariana Telles Silveira. 1999. Age differences between spouses in a Brazilian marriage sample. Evolution and Human Behavior 20: 99-103. [CrossRef]

Palmore, James A., and Masri Singarimbun. 1992. The conflicting effects of delayed marriage and declining divorce rates on cumulative fertility in Indonesia. Asian and Pacific Population Forum 6: 5-14. [PubMed]

Perreira, Petros T. 1991. Age at first marriage, education and divorce: The case of the U.S.A. Economia 15: 21-49.

Pili, Silvia, Efstatios Grigoriadis, Margherita Carlucci, Matteo Clemente, and Luca Salvati. 2017. towards sustainable growth? A multi-criteria assessment of (changing) urban forms. Ecological Indicators 76: 71-80. [CrossRef]

Pinnelli, Antonella, and Mariachiara Di Cesare. 2005. Human fertility: Sociodemographic aspects. Contraception 72: 303-7. [CrossRef] [PubMed]

Rindfuss, Ronald R., Karen Benjamin Guzzo, and S. Philip Morgan. 2004. The changing institutional context of low fertility. Population Research and Policy Review 22: 411-38. [CrossRef]

Rontos, Kostas. 2007. Prospects for a new family formation and for its impact on fertility: Some research evidences from Greece. Statistical Review 3: 49-67.

Rontos, Kostas. 2010. Demographic trends, young people's attitudes towards marriage and socio-economic changes related to family formation in Greece and in selected European Countries: A comparative analysis based on official and survey research data. International Journal of Criminology and Sociological Theory 3: 11-33.

Rontos, Kostas. 2020. Demographic Reality, Economic Crisis and the Policy (not) Imposed from the Governments in Greece. In Radicalism in Power: A Sociological Analysis of SYRIZA-ANEL Governance (2015-2019). Edited by Marangudakis Manussos, Tsakonas Panagiotis and Theodore Chatjipantelis. Athens: Sideris Publisher.

Rontos, Kostas, Efstatios Grigoriadis, Adele Sateriano, Maria Syrmali, Ioannis Vavouras, and Luca Salvati. 2016. Lost in Protest, Found in Segregation: Divided Cities in the Light of the 2015 'Oki' Referendum in Greece. City, Culture and Society 7: 139-48. [CrossRef]

Rontos, Kostas, M. Roumeliotou, L. Salvati, and M.-E. Syrmali. 2017. Marriage or Cohabitation? A Survey of Students' Attitudes in Greece. Demografia English Edition 60: 5-31.

Rosina, Alessandro, and Romina Fraboni. 2004. Is marriage losing its centrality in Italy? Demographic Research 11: 149-72. [CrossRef]

Salvati, Luca. 2016. The Dark Side of the Crisis: Disparities in per Capita income (2000-2012) and the Urban-Rural Gradient in Greece. Tijdschrift voor Economische en Sociale Geografie 107: 628-41. [CrossRef]

Salvati, Luca. 2018. Population growth and the economic crisis: Understanding latent patterns of change in Greece, 2002-2016. Letters in Spatial and Resource Sciences 11: 105-26. [CrossRef]

Salvati, Luca, and Margherita Carlucci. 2017. Urban Growth, Population and Recession: Unveiling Multiple Spatial Patterns of Demographic Indicators in a Mediterranean City. Population, Space and Place 23: e2079. [CrossRef]

Salvati, Luca, and Pere Serra. 2016. Estimating rapidity of change in complex urban systems: A multidimensional, local-scale approach. Geographical Analysis 48: 132-56. [CrossRef]

Seltzer, Judith A., Christine A. Bachrach, Suzanne M. Bianchi, Caroline H. Bledsoe, Lynne M. Casper, P. Lindsay Chase-Lansdale, Thomas A. DiPrete, V. Joseph Hotz, S. Philip Morgan, Seth G. Sanders, and et al. 2005. Explaining Family Change and Variation: Challenges for Family Demographers. Journal of Marriage and Family 67: 908-25. [CrossRef] 
Sobotka, Tomáš, Vegard Skirbekk, and Dimiter Philipov. 2011. Economic recession and fertility in the developed world. Population and Development Review 37: 267-306. [CrossRef]

Sobotka, Tomáš, Éva Beaujouan, and Jan Van Bavel. 2017. Introduction: Education and fertility in low-fertility settings. Vienna Yearbook of Population Research 15: 1-16. [CrossRef]

South, Scott J. 1993. Racial and ethnic differences in the desire to marry. Journal of Marriage and Family 55: 357. [CrossRef]

Todd, Peter M., Francesco C. Billari, and Jorge Simão. 2005. Aggregate age-at-marriage patterns from individual mate-search heuristics. Demography 42: 559-74. [CrossRef] [PubMed]

Tragaki, Alexandra, and Christos Bagavos. 2019. Fertility variations in the recession context: The case of Greece. Genus 75: 18. [CrossRef]

Tucker, M. Belinda, and Claudia Mitchell-Kernan. 1990. New trends in Black American interracial marriage: The social structural context. Journal of Marriage and the Family 52: 209-18. [CrossRef]

UNECE. 2003. Trends in Europe and North America: A Statistical Yearbook of the Economic Commission for Europe. Geneva: UNECE.

Van Bavel, Jan, and Joanna Różańska-Putek. 2010. Second birth rates across Europe: Interactions between women's level of education and child care enrolment. Vienna Yearbook of Population Research 8: 107-38. [CrossRef]

Van de Putte, Bart, Frans Van Poppel, S. Vanassche, M. Sanchez, S. Jidkova, M. Eeckhaut, M. Oris, and M. Matthijs. 2009. The rise of age homogamy in 19th century Western Europe. Journal of Marriage and Family 71: 1234-53. [CrossRef]

Van Poppel, Frans, and Jan Nelissen. 1999. The Proper Age to Marry: Social Norms and Behaviour in Nineteenth-Century Netherlands. The History of the Family 4: 51-75. [CrossRef]

Van Poppel, Frans, Aart C. Liefbroer, Jeroen K. Vermunt, and Wilma Smeenk. 2001. Love, necessity and opportunity: Changing patterns of marital age homogamy in the Netherlands, 1850-1993. Population Studies 55: 1-13. [CrossRef]

van Wissen, Leo J. G., and Liesbeth Heering. 2014. Trends and patterns in Euro-marriages in the Netherlands. Population, Space and Place 20: 126-38. [CrossRef]

Vera, Hernan, Donna H. Berardo, and Felix M. Berardo. 1985. Age heterogamy in marriage. Journal of Marriage and the Family, 553-66. [CrossRef]

Vitali, Agnese, and Francesco C. Billari. 2017. Changing determinants of low fertility and diffusion: A spatial analysis for Italy. Population, Space and Place 23: e1998. [CrossRef]

Voland, Eckart, and R. I. M. Dunbar. 1997. The impact of social status and migration on female age at marriage in an historical population in north-west Germany. Journal of Biosocial Sciences 29: 355-60. [CrossRef] [PubMed]

Wu, Zheng, and T. R. Balakrishnan. 1992. Attitudes towards cohabitation and marriage in Canada. Journal of Comparative Family Studies 23: 1-12. [CrossRef]

Yan, Yunxiang. 2015. Parent-driven divorce and individualisation among urban Chinese youth. International Social Science Journal 64: 213-14. [CrossRef]

Yoo, Sam Hyun. 2016. Postponement and recuperation in cohort marriage: The experience of South Korea. Demographic Research 35: 1045-78. [CrossRef]

Zaidi, Batool, and S. Philip Morgan. 2017. The second demographic transition theory: A review and appraisal. Annual Review of Sociology 43: 473-92. [CrossRef] [PubMed]

Zambon, Ilaria, Pere Serra, David Sauri, Margherita Carlucci, and Luca Salvati. 2017. beyond the 'Mediterranean city': Socioeconomic disparities and urban sprawl in three Southern European cities. Geografiska Annaler: Series B, Human Geography 99: 319-37. [CrossRef]

Zhang, Yuping, Emily Hannum, and Meiyan Wang. 2008. Gender-based employment and income differences in urban China: Considering the contributions of marriage and parenthood. Social Forces 86: 1529-60. [CrossRef]

Zitti, Marco, Carlotta Ferrara, Luigi Perini, Margherita Carlucci, and Luca Salvati. 2015. Long-term urban growth and land use efficiency in Southern Europe: Implications for sustainable land management. Sustainability 7: 3359-85. [CrossRef]

(C) 2020 by the authors. Licensee MDPI, Basel, Switzerland. This article is an open access article distributed under the terms and conditions of the Creative Commons Attribution (CC BY) license (http://creativecommons.org/licenses/by/4.0/). 